\title{
Efficacy of Insecticide Formulation of Organo Phosphate 5 Ec Mixture of Maltahion on Mosquito Aedes Aegypti
}

\author{
Edy Supriyo*, Wisnu Broto, Isti Pujiastuti and Fahmi Arifan
}

Vocational School of Diponegoro University, Semarang - Indonesia

\begin{abstract}
Efficacy insecticide of organophosphate 5 EC formulation mixture of $20 \%$ malathion and $10 \%$ permentrin on mosquito Aedes aegypti was studied. The experiment use quatro of 25 individus of mosquitos during 24 hours observation to determinine their mortality after being sprayed with 1 gram of active ingredient in peet grady chamber. The result of the study revealed that $98 \%$ mortality of mosquito Aedes aegypti during 3 minutes treatment and 100\% mortality ini 4 minutesA concise and factual abstract is required.
\end{abstract}

Keywords: EC ; Organophosphate ; spray insecticide

\section{Introduction}

The application of insecticide as vector control has been widely conducted. Vector control to eradicate dengue hemorrhagic fever is an effort to broke the transmission of the disease. One way to do that is by fogging, such as thermal fogging and ultra low volume (cold fogging). Beside bendiocarb of carbamate group insectide [1], malathion belongs to organophosphate has beed applied in Indonesia since 1972 [2]. Malathion is commonly used as active agent of insecticide to which the mosquitos A. aegypti resistence. According to [3] this resistence was due to continuous application of one kind of insecticide so build the immunity up in the mosquitos. Even larvae of A. aegypti has also already resistence to Temephos (Abate) $[4,5,6]$ which is consisted of Tetramethyil Thiodi. P-Phenylene, Phasphorothioate 1\% and inert ingredient 99\% [7]. Therefore it is important to get a new insecticide active agent.

In order to get alternative insecticide, the study of using single or mixture of active agent need to be carried out. Combination of insecticide from organophosphate and carbamate group has been conducted by [8] using malathion and propuxur respectively. The result showed that physical properties of those formulation is matched with Indonesian Pesticide Commission standard. Recently, sinthetic insecticide belong to piretroid group, i.e. Permentrin has been recommended to mosquito Aedes aegypti as a vector of Dengue Hemorrhagic Fever/DHF [9]. Efficacy test of permethrin $(100 \mathrm{~g} / \mathrm{l})$ as insecticide active agent has been conducted to several vector such as A. aegypti (dengue hemorrhagic fever), Culex quinquefasciatus (filariasis) and Anopeles aconitus (malaria) using thermal fogging method [10].
The aim of present work was to test the efficacy of insecticide of organophosphate 5 EC formulation mixture of $20 \%$ malathion and $10 \%$ permentrin on mosquito Aedes aegypti Semarang strain. The finding of new more effective pesticide is hope to contribute to building a low carbon development, achieving Indonesia's climate actions target, and sustainable food, industry and land use economy in Indonesia.

\section{Materials and Method}

The formulation of insecticide was done in PT. Bina Guna Kimia-Semarang and efficacy test was in Entomology Laboratory, Animal Medical Faculty of Bogor Agricultural University. Liquid insectiside formulation Organophosphate 5 EC consists of malathion $20 \%$ and permentrin $10 \%$ was tested to three days old mosquitos A. aegypti Semarang Strain in peet grady chamber size of $1900 \mathrm{~mm}$ x $1900 \mathrm{~mm}$ x $1900 \mathrm{~mm}$. The efficacy test was done four times using twenty five mosquitos A. aegypti.

Mosquitos A. aegypti were put into peet grady chamber one hour prior to the test to certain that they are healthy live mosquitos. The test insecticide (Table 1) was sprayed into chamber using electric sprayer as much as 1,00 gram. The mosquitos which was fallen (knock down) in every minutes was counted during first 10 minute, then was counted in every ten minutes for 60 minutes. After 1 hour the treatment was taken out from the chamber and was examined for the recovery and after that was put back in the cahamber. To observe whether mosquitos recover from insecticide, in every

* Corresponding author: edyspy2000@yahoo.co.id 
hour was observed up to 6 hour. The observation was carried out for 24 hours.

Fallen (knock down) number of mosquito was determined using probitability analyses to calculated 50 and $90 \%$ fallen time. The insecticide was effective when $90 \%$ fallen tine not more than 15 minutes and mortality more than $90 \%$ in 24 hours.

Table 1. Formulation of tested insecticide organophosphate 5 EC [8]

\begin{tabular}{lc}
\hline Composition & Consentration \\
\hline Malathion (gram) & 20 \\
Permentrin (gram) & 10 \\
Agrisol (gram) & 5 \\
Xyline (gram) & 55 \\
Iso propyl Alkohol & 4 \\
Propyline Glycol & 4 \\
(gram ) & \\
Tolune (gram) & 2 \\
Endapan (gram) & 0,005 \\
Total (gram ) & 100
\end{tabular}

\section{Results and Discussion}

The tested insecticide formulation had $300 \mathrm{gr} / \mathrm{lt}$ active agent and $5 \mathrm{gr} / \mathrm{lt}$ emulsifier, and $550 \mathrm{gr} / \mathrm{lt}$ solvent. Although this consentration of active ingredient, emulsifier and solvent were lower than Indonesian Pesticides Commision Standard (404 gr/lt, 580 gr/lt, and $550 \mathrm{gr} / \mathrm{lt}$ respectively) their value are still high, that will affect the colour of insecticides [8].

Efficacy test them was performed in petty grady chamber using mosquitos of A. aegypti. The room temperatuwe was $28^{\circ} \mathrm{C}$ and humidity was $50 \%$. The result was shown in Table 2.

The result of present work (Table 2) revealed that 1,00 gram liquid insecticide wih active agent organophosphate $5 \mathrm{EC}$ with $20 \%$ malathion and $10 \%$ permentrin sprayed in peet grady chamber was very effective to knock down and kill the $A$. aegypti mosquitos in which $98 \%$ mosquitos know downed in 3 minutes and all were killed in 4 minute. There were no mosquitos recover alive in 24 hours. This result was much better that previous studies. The experiment by [10] using organophosphate group with permentrin revealed the A. aegypti mosquitos mortality of 79,2 and $100 \%$ during 50 minutes and 2 hours respectively. While the work of [11] gave result of 1 gram mixture of organophosphate dan carbamat group with $20 \%$ malathion and $10 \%$ propoxure sprayed in peet grady chamber, knock down time A. aegypti mosquitos was $5 \%$ in 8 hours, and the mortality was only $85 \%$ in 24 hours.
Using only organophosphate group, i.e. malathion (in control grup) this experiment showed no mortality during 24 hours. It meant that the mosquitos has already resistance to malathion as found by [12].

Table 2. Efficacy test of tested formulation

\begin{tabular}{|c|c|c|c|c|c|c|}
\hline \multirow{2}{*}{ Time } & \multicolumn{4}{|c|}{ Knock down } & \multirow{2}{*}{$\begin{array}{c}\text { Average } \\
(\%)\end{array}$} & \multirow{2}{*}{ Control } \\
\hline & 1 & 2 & 3 & 4 & & \\
\hline 0'00" & 0 & 0 & 0 & 0 & 0,00 & 0,00 \\
\hline 1'00" & 40 & 48 & 48 & 40 & 41,00 & 0,00 \\
\hline 2'00" & 84 & 88 & 80 & 72 & 81,00 & 0,00 \\
\hline 3'00" & 100 & 100 & 100 & 92 & 98,00 & 0,00 \\
\hline 4'00" & 100 & 100 & 100 & 100 & 100,00 & 0,00 \\
\hline 5'00" & 100 & 100 & 100 & 100 & 100,00 & 0,00 \\
\hline 6'00" & 100 & 100 & 100 & 100 & 100,00 & 0,00 \\
\hline 7'00" & 100 & 100 & 100 & 100 & 100,00 & 0,00 \\
\hline 8'00" & 100 & 100 & 100 & 100 & 100,00 & 0,00 \\
\hline 9'00" & 100 & 100 & 100 & 100 & 100,00 & 0,00 \\
\hline $10^{\prime} 00^{\prime \prime}$ & 100 & 100 & 100 & 100 & 100,00 & 0,00 \\
\hline 20'00" & 100 & 100 & 100 & 100 & 100,00 & 0,00 \\
\hline 30'00" & 100 & 100 & 100 & 100 & 100,00 & 0,00 \\
\hline $40^{\prime} 00^{\prime \prime}$ & 100 & 100 & 100 & 100 & 100,00 & 0,00 \\
\hline 50'00" & 100 & 100 & 100 & 100 & 100,00 & 0,00 \\
\hline \multirow[t]{2}{*}{1 Hour } & 100 & 100 & 100 & 100 & 100,00 & 0,00 \\
\hline & \multicolumn{6}{|c|}{ Out from peet grady } \\
\hline 2 Hour & 100 & 100 & 100 & 100 & 100,00 & 0,00 \\
\hline 3 Hour & 100 & 100 & 100 & 100 & 100,00 & 0,00 \\
\hline 4 Hour & 100 & 100 & 100 & 100 & 100,00 & 0,00 \\
\hline 5 Hour & 100 & 100 & 100 & 100 & 100,00 & 0,00 \\
\hline \multirow[t]{2}{*}{6 Hour } & 100 & 100 & 100 & 100 & 100,00 & 0,00 \\
\hline & \multicolumn{6}{|c|}{ Mortality } \\
\hline 24 Hour & 100 & 100 & 100 & 100 & 100,00 & 0,00 \\
\hline
\end{tabular}

\section{Conclusion}

Liquid insecticide wih active agent organophosphate 5 EC with $20 \%$ malathion and $10 \%$ permentrin was very effective for A. aegypti mosquitos. This finding is sure give better contribution to build a low carbon development in pesticide industrial sector.

\section{Acknowlegdments}

The author with to thank to PT. Bina Guna Kimia for the chemicals and to Entomology Laboratory, Animal Medical Faculty of Bogor Agricultural University for their facilities.

\section{References}

1. Z. Badarudin, Propoxure. Penerbit PT. Prabawa Dibya Weluarta Jakarta. 329 hal. (1997). 
2. Hendartini. Penelitian Pembuatan Formulasi Pestisida Bentuk Pekatan Yang Dapat Diemulsikan. Balai Besar Penelitian dan Pengembangan Industri Kimia, Departemen Perindustrian dan Perdagangan. Jakarta. Hal 23. (2003).

3. R. Nusa, M. Ipa, T. Delia, S. Marlia. Penentuan Status Resistensi Aedes aegypti dari Endemis DBD Di Kota Depok Terhadap Malation. Bul. Penelit Kesehat. 361 20-25 (2008)

4. A. Gafur, Mahrina, Hardiansyah. Kerentanan Larva Aedes Aegypti dari Banjarmasin Utara terhadap Temephos. Tesis. Bioscientiae III (2). Available at: $<$.http;//www.unlam .ac.idlbiosaentiael.> (2006).

5. M.R. Ridha, K. Nisa. Larva Aedes aegypti sudah toleran terhadap temepos di kota Banjarbaru, Kalimantan Selatan. Jurnal vektora III 2 93-111 (2011)

6. H. Fuadzy, D.N. Hodijah, A. Jajang, M. Widawati. Kerentanan larva Aedes aegypti terhadap temefos di tiga kelurahan Endemis demam berdarah dengue Kota Sukabumi. Bul. Penelit. Kesehat, 43 1 41-46 (2015)

7. A. Ponlawat, J.G. Scott, L.C. Harrington. Insecticide Susceptibility of Aedes aegypti and Aedes albopictus across Thailand. J. Med. Entomology 42 821-825 (2005).
8. E. Supriyo, F.S. Nugraheni, Z. Abidin. Formulasi Insektisida Cair Bentuk EC Yang Efektif Guna Membasmi Nyamuk Aedes Aegypti dalam Usaha Mencegah Penyakit DBD dan Zika Prosiding Seminar Nasional Teknologi SV UGM 2016. 174178 (2016)

9. IRAC (Insecticide Resistance Action Comitte). Prevention, and Management of Insecticide Resistance in Vector of Public Health Importance (2010)

10. L. Susanti, H. Boesri. Pengaruh insektisida sipermethrin $100 \mathrm{~g} / \mathrm{l}$ terhadap nyamuk dengan metode pengasapan. KEMAS 72 151-158 (2012).

11. E. Supriyo, I. Pujiastuti, W. Broto. Efikasi Formula Insektisida Berbahan Aktif Propoxure Dan Malathion Terhadap Vektor Penyakit DBD. METANA 14 1 7-10 (2018).

12. S.J. Soenjono, Suwarja, M.M. Pandean Status Resistensi Vektor Demam Berdarah Dengue Aedes aegypti terhadap Malathion di Kota Tomohon. $\begin{array}{lllll}\text { Jurnal Vektor Penyakit } & 11 & 2 & 43-48\end{array}$ https://doi.org/10.22435/vektorp.v11i2.6470.43-48 (2017) 